\title{
Frequency of islet cell autoantibodies (IA-2 and GAD) in young Brazilian type 1 diabetes patients
}

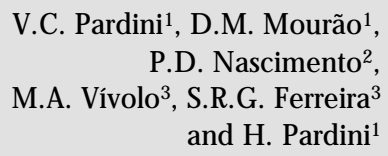

\section{Correspondence}

V.C. Pardini

Rua Aimorés, 33

30140-070 Belo Horizonte, MG

Brasil

Fax: + 55-31-221-7105

E-mail: vpardini@ labhpardini.com.br

Publication supported by FAPESP.

Received October 7, 1998

Accepted July 12, 1999

\author{
IInstituto de Patologia Clínica H. Pardini, Belo Horizonte, M G, Brasil \\ ${ }^{2}$ Hospital Felício Rocho, Belo Horizonte, MG, Brasil \\ ${ }^{3}$ Departamento de M edicina Preventiva, \\ Universidade Federal de São Paulo, São Paulo, SP, Brasil
}

\section{Abstract}

Type 1 diabetes, as an autoimmune disease, presents several islet cellspecific autoantibodies such as islet cell antibody (ICA), anti-insulin, anti-glutamic acid decarboxylase (GAD) and the antibody (Ab) against tyrosine phosphatase (PTP)-like protein known as ICA-512 (IA-2). In order to determine the frequency of the anti-GAD and anti-IA-2 autoantibodies in Brazilian type 1 diabetes patients we studied 35 diabetes mellitus (DM) type 1 patients with recent-onset disease $(\leq 12$ months) and 37 type 1 diabetes patients with long-duration diabetes ( $>12$ months) who were compared to 12 children with normal fasting glucose. Anti-GAD ${ }_{65}$ and anti-IA-2 autoantibodies were detected with commercial immunoprecipitation assays. The frequency of positive results in recent-onset DM type 1 patients was $80.0 \%$ for GADAb, $62.9 \%$ for IA-2Ab and $82.9 \%$ for GADAb and/or IA-2Ab. The longduration type 1 diabetes subjects presented frequencies of $54.1 \%$ for GADAb and IA-2Ab, and $67.5 \%$ for GAD and/or IA-2 antibodies. The control group showed no positive cases. Anti-GAD and IA-2 assays showed a high frequency of positivity in these Brazilian type 1 diabetes patients, who presented the same prevalence as a Caucasian population.

Type 1 diabetes is a chronic autoimmune disease caused by the destruction of insulinsecreting islet cells of the pancreas $(1,2)$ by several islet cell-specific autoantibodies. These autoantibodies are valuable markers to predict type 1 diabetes and can be detected many months or years before the onset of diabetes (3).

Many autoantibodies against $\beta$-cells have been identified. The most important ones are: islet cell antibody (ICA) (1), anti-insulin (3), anti-glutamic acid decarboxylase (GAD) (4) and the antibody ( $\mathrm{Ab}$ ) against the tyrosine phosphatase (PTP)-like protein known

\section{Key words}

- Type 1 diabetes

- Autoimmunity

- GAD and IA-2

autoantibodies as ICA-512 (IA-2) (5,6). Antibodies against GAD and IA-2 can be detected in type 1 diabetes patients using radioimmunoassays. These autoantibodies have been useful in differentiating late-onset type 1 from type 2 diabetes occurring in young adulthood (7). In addition, they have been used to confirm the autoimmune process in gestational diabetes ( 8 ) and to separate type 1 diabetes from other types of non-autoimmune diabetes like maturity-onset diabetes of the young (9) or diabetes related to mitochondrial DNA mutation (10). Knowing the frequency of these autoantibodies in a population is an impor- 
tant step for a better understanding and diagnosis of type 1 diabetes.

This study was conducted using commercial assays to determine the frequency of anti-GAD and anti-IA-2 autoantibodies in serum of young Brazilian type 1 diabetes patients with recent-onset and long-duration diabetes.

We studied 35 type 1 diabetes patients (16 females, $13.2 \pm 5.7$ years) who had been diagnosed with diabetes within one year prior to the study. These subjects were called recent-onset diabetes patients. Thirty-seven type 1 diabetes patients (19 females, $13.9 \pm$ 3.3 years) who had had diabetes for more than one year were also studied and were called long-duration diabetes patients. These groups were compared to 12 children $(11.8 \pm$ 4.4 years $)$ with normal fasting glucose $(<100$ $\mathrm{mg} / \mathrm{dl}$ ) and no family history of type 1 diabetes (Table 1). The type 1 diabetes patients were selected while attending a diabetes vacation camp and all patients' mothers gave informed consent to collect blood samples to perform this study. Diabetes was diagnosed according to World Health Organization cri-

Table 1 - Clinical characteristics of type 1 diabetes patients and control subjects.

F/M, Female/male; ns, nonsignificant (Mann-Whitney U-test).

\begin{tabular}{lrrcc}
\hline & \multicolumn{2}{c}{ Type 1 diabetes } & Control group & P \\
\cline { 2 - 4 } & \multicolumn{2}{c}{ Recent-onset } & Long-duration n & \\
\hline N (F/M) & $35(16 / 19)$ & $37(19 / 18)$ & $12(3 / 9)$ & \\
Age (years) & $13.2 \pm 5.7$ & $13.9 \pm 3.3$ & $11.8 \pm 4.4$ & ns \\
Duration of diabetes (months) & $6.5 \pm 4.0$ & $50.7 \pm 30.0$ & - & $<0.005$ \\
Dose of insulin (U/day) & $27.6 \pm 17.1$ & $44.7 \pm 14.4$ & - & $<0.005$
\end{tabular}

Table 2 - Prevalence of anti-glutamic acid decarboxylase (GAD) and ICA-512 (IA-2) antibodies in type 1 diabetes patients with recent-onset and long-duration diabetes (Fisher's exact test).

\begin{tabular}{lccc}
\hline & GAD & IA-2 & GAD and/or IA-2 \\
\hline Recent-onset diabetes & $80.0 \%(28 / 35)$ & $62.9 \%(22 / 35)$ & $82.9 \%(29 / 35)$ \\
Long-duration diabetes & $54.1 \%(20 / 37)$ & $54.1 \%(20 / 37)$ & $67.5 \%(25 / 37)$ \\
Control group & $0.0 \%(0 / 12)$ & $0.0 \%(0 / 12)$ & $0.0 \%(0 / 12)$
\end{tabular}

teria (11).

Anti-GAD 65 and anti-IA-2 autoantibodies were detected with commercial immunoprecipitation assays using ${ }^{125}$ I-labeled human recombinant $\mathrm{GAD}_{65}$ and $\mathrm{IA}-2$, respectively (RSR Ltda., Cardiff, UK). The lower detection limit was $0.1 \mathrm{U} / \mathrm{ml}$ for both assays. The reference values used, based on our controls, for anti-GAD 65 and anti-IA-2 were $<1.0$ and $\leq 0.5 \mathrm{U} / \mathrm{ml}$, respectively. These cutoff levels for positivity were established using the 99th percentile of the control groups. The test serum samples were first incubated with ${ }^{125}$ I-labeled human recombinant protein $\left(\mathrm{GAD}_{65}\right.$ and IA-2), followed by the addition of solid phase protein A to precipitate the labeled protein and antibody complex. After centrifugation, ${ }^{125} \mathrm{I}$ was counted in the precipitates. The amount of radioactivity in the precipitates was proportional to the concentration of IA-2 antibody in the test sample. The intra-assay and the inter-assay coefficients of variation $(\mathrm{CV})$ for anti-GAD 65 were 3.1 and $3.5 \%$, respectively, for normal reference values. The intra-assay CV for IA-2 was $4.3 \%$ and the inter-assay $\mathrm{CV}$ was $3.4 \%$ for normal reference values.

Data are reported as mean \pm SEM, unless otherwise stated. The Mann-Whitney U-test was used when comparing two groups. Statistical analyses were performed using a Fisher's exact probability test. The correlation between two variables was determined using Spearman's test. Data were analyzed with the Statistical Package for Social Science for Windows, version 7.0 (SPSS Inc., Chicago, IL, USA). A P value of less than 0.05 was considered statistically significant.

Among the 35 recent-onset type 1 diabetes patients, $28(80.0 \%)$ were positive for GADAb, $22(62.9 \%)$ were positive for IA$2 \mathrm{Ab}$, and $29(82.9 \%)$ were positive for GADAb and/or IA-2Ab. Among the 37 longduration type 1 diabetes subjects, $20(54.1 \%)$ were positive for GADAb and IA-2Ab, and $25(67.5 \%)$ were positive for GAD and/or IA-2 antibodies (Table 2). All individuals in 
the control group had results within the reference values. Duration of type 1 diabetes showed a significant negative correlation with autoantibody levels (GADAb $r=-0.23$, $\mathrm{P}<0.05$; IA- $2 \mathrm{Ab} r=-0.25, \mathrm{P}<0.04)$.

In the recent-onset diabetic population, GAD frequency was higher than IA-2 frequency and their combination did not increase the prevalence of positive assays. However, in long-duration type 1 diabetes patients, combining these antibodies improved the probability of detection of an autoimmune reaction. The Brazilian population studied here had the same GADAb prevalence as that reported in Caucasian patients (65-84\%) and Asian type 1 diabetes patients (5-83.3\%) (12-14).

IA-2 autoantibody is present in approximately $60 \%$ of recent-onset type 1 diabetes patients $(15,16)$, which is consistent with our findings. Also, testing for both antibodies increases positive results in type 1 diabe- tes patients, even in long-duration ones.

Some studies have also shown that the combined analysis of GADAb and IA-2Ab is more effective in detecting type 1 diabetes than the histochemical ICA test, which is an important advantage because the ICA test is technically difficult to perform, requires human pancreatic tissue and has low reproducibility $(17,18)$. Anti-GAD and IA-2 assays showed a high frequency of positivity in these Brazilian type 1 diabetes patients and these patients presented the same prevalence as a Caucasian population reported by others (12).

\section{Acknowledgments}

We are grateful to the doctors, residents, nurses and staff of the "Nosso Recanto" Diabetes Campus for their help with protocols.

\section{References}

1. Eisenbarth GS (1986). Type I diabetes mellitus: a chronic autoimmune disease. New England J ournal of Medicine, 314: 1360-1368.

2. Leslie RDG \& Gale EAM (1995). Etiology of insulin dependent diabetes. In: Leslie RDG \& Robbins DC (Editors), Diabetes; Clinical Science in Practice. Cambridge University Press, Cambridge, 134-156.

3. Verge CF, Gianani R, Kawasaki E, Yu L, Pietropaolo M, J ackson RA, Chase HP \& Eisenbarth GS (1996). Prediction of type I diabetes in first degree relatives using a combination of insulin, GAD and ICA-512/ IA-2 antibodies. Diabetes, 45: 926-933.

4. Baekkeskov S, Aanstoot HJ , Christgau S, Reetz A, Solimena M, Cascalho M, Folli F, Richter-Olesen H \& DeCamilli P (1990). Identification of the $64 \mathrm{~K}$ autoantigen in insulin dependent diabetes as the GABAsynthesizing enzyme glutamic acid decarboxylase. Nature, 347: 151-156.

5. Rabin DU, Pleasic SM, Shapiro J A, YooWarren H, Oles J , Hicks J M, Goldstein DE \& Era PMM (1994). Islet cell antigen 512 is a diabetes-specific islet autoantigen related to protein tyrosine phosphatases.
J ournal of Immunology, 152: 3183-3188.

6. Lan MA, Lu J , Goto Y \& Notkins AL (1994). Molecular cloning and identification of a receptor-type protein tyrosine phosphatase, IA-2, form human insulinoma. DNA and Cell Biology, 13: 505-514.

7. Tuomi T, Groop LC, Zimmet PZ, Rowley MJ , Knowles W \& Mackay IR (1993). Autoantibodies to glutamic acid decarboxylase reveal latent autoimmune diabetes mellitus in adults with a non-insulin-dependent onset of diabetes. Diabetes, 42 : 359-362.

8. Füchtenbusch $M$, Ferber $K$, Standl $E$ \& Ziegler AG (1997). Prediction of type 1 diabetes postpartum in patients with gestational diabetes mellitus by combined islet cell autoantibody screening. Diabetes, 46: 1459-1467.

9. Dussoix $P$, Vaxillaire $M$, Iynedjian $P B$, Tiercy J M, Ruiz J , Spinas GA, Berger W, Zahnd G, Froguel P \& Philippe J (1997). Diagnostic heterogeneity of diabetes in lean young adults - classification based on immunological and genetic parameters. Diabetes, 46: 622-631.

10. Reardon W, Ross RJ, Sweeney MG,
Luxon LM, Pembrey ME, Harding AE \& Trembath RC (1992). Diabetes mellitus associated with a pathogenic point mutation in mitochondrial DNA. Lancet, 340: 1376-1379.

11. World Health Organization Diabetes Mellitus (1985). Report of a WHO Study Group. Technical Report Series, No. 727, WHO, Geneva.

12. Schmidli RS, Colman PG \& Bonifacio E (1995). Disease sensitivity and specificity of 52 assays for glutamic acid decarboxylase antibodies: The second international GADAb Workshop. Diabetes, 44: 636640.

13. Akamine H, Komiya I, Shimabukuro $T$, Asawa T, Tanaka H, Yagi N, Taira T, Nagata K, Arakaki K, Wakugami T, Takasu N, Powell MJ , Furmaniak J \& Smith BR (1997). High prevalence of GAD65 (and IA-2) antibodies in J apanese IDDM patients by a new immunoprecipitation assay based on recombinant human GAD65. Diabetic Medicine, 14: 778-784.

14. Zimmet PZ, Rowley MJ, Mackay IR, Knowles WJ , Chen QY, Chapman LH \& Serjeantson SW (1993). The ethnic distri- 
bution of antibodies to glutamic acid decarboxylase: presence and levels in insulin-dependent diabetes mellitus in European and Asian subjects. J ournal of Diabetes Complication, 7: 1-7.

15. Gorus FK, Goubert P, Semakula C, Vandewalle CL, De Schepper J , Scheen A, Christie MR \& Pipeleers DG (1997). IA2-autoantibodies complement GAD-65autoantibodies in new-onset IDDM patients and help predict impeding diabetes in their siblings. Diabetologia, 40: 95-99.
16. Vandewalle $C L$, Falorni $A$, Lernmark $A$, Goubert P, Dorchy H, Coucke W, Semakula C, Auwera BVD, Kaufman L, Schuit FC, Pipeleers DG \& Gorus FK (1997). Association of GAD-65 and IA-2 autoantibodies with genetic risk markers in new-onset IDDM patients and their siblings. Diabetes Care, 20: 1547-1552.

17. Ladenburger UW, Hartmann R, Hartmann U, Berting K, Böhn BO \& Richter W (1997). Combined analysis and single-step detection of GAD 65 and IA-2 autoanti- bodies in IDDM can replace the histochemical islet cell antibody test. Diabetes, 46: 565-571.

18. Borg H, Fernlund P \& Sundkvist G (1997). Protein tyrosine phosphatase-like protein IA-2-antibodies plus glutamic acid decarboxylase 65 antibodies (GADA) indicate autoimmunity as frequently as islet cell antibodies assay in children with recently diagnosed diabetes mellitus. Clinical Chemistry, 43: 2358-2363. 